Journal of Southeast Asian

\title{
Book Review: Juks Adventure in Phuket Thailand by Meng Lin Chen and Michael Kirjon
}

Mariana Kuhl

marianakuhl@gmail.com

Follow this and additional works at: https://docs.lib.purdue.edu/jsaaea

Part of the Asian American Studies Commons

\section{Recommended Citation}

Kuhl, Mariana (2010) "Book Review: Juks Adventure in Phuket Thailand by Meng Lin Chen and Michael Kirjon," Journal of Southeast Asian American Education and Advancement. Vol. 5 : Iss. 1, Article 12. DOI: 10.7771/2153-8999.1013

Available at: https://docs.lib.purdue.edu/jsaaea/vol5/iss1/12

This document has been made available through Purdue e-Pubs, a service of the Purdue University Libraries. Please contact epubs@purdue.edu for additional information.

This is an Open Access journal. This means that it uses a funding model that does not charge readers or their institutions for access. Readers may freely read, download, copy, distribute, print, search, or link to the full texts of articles. This journal is covered under the CC BY-NC-ND license. 


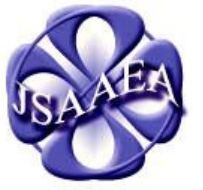

Volume 5 (2010)

\section{Journal of Southeast Asian American \\ Education \& Advancement}

WwW.JSAAEA.org
A peer-reviewed

scholarly journal

published by the

National Association

for the Education \&

Advancement of

Cambodian, Laotian, and Vietnamese

Americans (NAFEA)

\title{
Book Review
}

\section{Meng, L. C., \& Kirjon, M (2005). Juk's Adventure in Phuket Thailand. Phuket, Thailand : Asia Design Consultants. 24 pp. ISBN: 97449287622.}

\author{
Reviewed by \\ Mariana Kuhl, M.A.
}

When I opened the book Juk's Adventure in Phuket Thailand, I was captured by the beauty of all of the colors and languages encompassed within its pages. It is simply written and realistically captures different aspects of the culture in Phuket, Thailand. Each page contains one straightforward statement pertaining to daily life in Phuket like "This is my house, we leave our shoes outside." It then moves on to Juk's daily routine; for example, Juk begins his week by going to the beaches, on Tuesdays he goes to the jungle, Wednesdays to the cave, Thursdays to the market, Fridays he goes swimming, Saturdays he goes to visit his grandma, and Sundays he goes to milk the rubber trees. He ends the book with different activities that are important to the culture such as helping baby turtles walk to the beach. Juk's Adventure books are great for elementary level students, and especially for ESL (English as a Second Language) classrooms.

The teacher can interact with the students as the book is being read and ask them questions like "do you leave your shoes outside every time you go in to your house?" They can explain to the students that different cultures have varying daily traditions and they can discuss some that are different or similar to Juk's. A variety of discussion opportunities are readily available throughout the book.

The authors have pictures that go along with each description plus a translation of the sentence in nine different languages including English, Thai, Japanese, Chinese, Spanish, Swedish, German, French, and Italian. Therefore, this book would make a great addition to any ESL teacher's classroom and would benefit all of the students by exposing them to different cultures and languages. Reading the book could establish a new beginning for students to explore and appreciate different cultures. The visual exposure to the written form of foreign languages could potentially become an opportunity for group discussion as well.

The following section lists some ideas that teachers can incorporate into their classrooms as well as things that parents could do at home with their children. I have found Juk's adventure books to be a positive addition to any children's library. 


\section{Activities That Correspond to This Book:}

1. At the end of the book are vocabulary words that classroom teachers can use to introduce to students before reading the book. One activity is to introduce the words, describe them, and have the students discuss them. When the teacher reads the book, the students can also look for the words in the book. Once they find the words, students and teachers can discuss their meanings together. After reading the book the children could make a dictionary of the vocabulary words that were discussed. Each entry might contain a picture, a definition, and a sentence describing the word. If the student is an ESL student, he or she could make a bilingual dictionary in their language and English.

2. Students can do a sequencing activity of what Juk did on Monday, Tuesday, Wednesday, etc. The students can do this by drawing pictures of what Juk did every day of the week. Another option is to make cards of the activities that Juk did, and/or the teacher can make puppets of Juk's activities on popsicle sticks. Afterwards, the students can describe the sequence of the activities as a whole group and then break up into small groups and repeat the sequence.

3. More advanced students could do research about Juk's activities and give more details about what Thai people do. The students can make a poster of each activity and describe it in groups or as individuals. Investigating stories can make them seem more real and makes teaching more interesting. The learning experience, in turn, may become more intriguing and lasting for students.

4. The students can pretend they are Juk and pick a day of the week they like the most and journal about their experience adding more details to their activity.

5. The students can reflect on cultural differences and describe whether or not they would like to do those activities.

6. For beginner students, this is a good book to review the days of the week. The teacher could introduce a daily or weekly routine.

7. The students can write a story with the vocabulary words provided at the back of the book. For example, they could be asked to use one vocabulary word per sentence followed by illustration activation for each sentence.

8. The students could role play Juk's weekly routine and expand on the sentences and/or add more details.

9. The students could record one thing they do each day of the week and illustrate it. For example, on Monday I read a book. On Tuesdays I go to the park, etc. (This can be done before or after reading the book.) Then they might compare and contrast it to Juk's routine.

10. The students could research other activities that people from Phuket, Thailand regularly participate in. They could present this to the class with visuals in groups, partners, or individually. 
11. An enrichment activity that students could participate in could be to make personal connections to the book. For instance, if they have had any experiences similar to Juk's, they might be encouraged to share it with the class and bring in pictures and realia, if possible.

12. If teachers find that they do not have enough time to incorporate a book like this in the classroom, they could have the student take it home, read it with their parents and do an activity about it for homework and return it a few days later. (Teachers may want to consider having students and their families sign a contract to pay for the book if it gets lost.)

There is a collection of Juk's adventures found at www.juksadventures.com and this book has been purchased in Bangkok, Thailand at a store called Asia Books. More of these books can be found at www.asiabooks.com. I highly recommend this book to elementary school teachers, especially those working with ESL students.

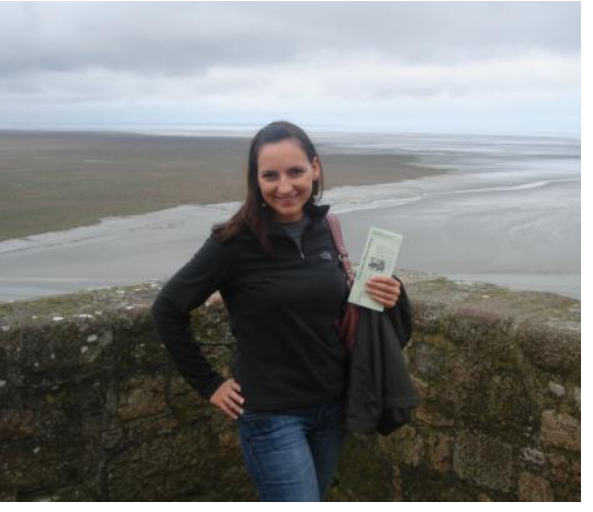

Mariana Rojas Kuhl has taught three years in the Texas public school system for Northside Independent School District (NISD). She received first year educator of the year award in 2005, presented at the NISD ESL Summer Institute in 2008, and taught English to high school students in Thailand in 2008 and 2010. Mariana received her Bachelor's degree in Psychology from Texas A\&M University in 2002 and her Master's in TESL (Teaching English as a Second Language) from the University of Texas in San Antonio in 2009. She has a true passion for traveling and promoting education throughout the world. 


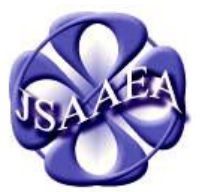

Volume 5(2010)

\section{Journal of Southeast Asian American Education \& Advancement WWW.JSAAEA.org}

\section{Editor}

Dr. Wayne E. Wright

University of Texas, San Antonio

Associate Editors

Dr. Chhany Sak-Humphry

University of Hawaii

Dr. KimOanh Nguyen-Lam

California State University, Long Beach

Book Review Editor

Dr. Vichet Chhuon

University of Minnesota

Creative Works Editor

Bryan Thao Worra

Lao Assistance Center

Special Advisor

Gregory Green

Curator, Echols Collection on Southeast Asia, Cornell University Library

\section{Editorial Assistant}

Kathleen Langham

University of Texas, San Antonio
A peer-reviewed scholarly journal published by the National Association for the Education \& Advancement of Cambodian, Laotian, and Vietnamese Americans (NAFEA)

Comments and questions for the editorial staff may be directed to jsaaea@ lists.sis.utsa.edu

\section{Editorial Review Board}

Dr. Carl L. Bankston III

Tulane University

Dr. Phala Chea

Lowell Public Schools

Dr. Loan Dao

Cancer Prevention Institute of California

Dr. Sophal Ear

U.S. Naval Postgraduate School

Dr. Samlong Inthaly

Minneapolis Public Schools
Dr. Pollie Bith-Melander

Asian and Pacific Islander Wellness Center

Dr. George Chigas

University of Massachusetts, Lowell

Dr. Changming Duan

University of Missouri, Kansas City

Dr. Nancy H. Hornberger

University of Pennsylvania

Dr. Peter Nien-Chu Kiang

University of Massachusetts, Boston 
Kuhl-Book Review of Juk's Adventure in Phuket Thailand

\author{
Dr. Kevin K. Kumashiro \\ University of Illinois, Chicago \\ Dr. David Chanpannha Ley \\ Montgomery County Public Schools \\ Dr. Bic Ngo \\ University of Minnesota \\ Dr. Leakhena Nou \\ California State University, Long Beach \\ Dr. Mark Pfeifer \\ Texas A\&M University, Corpus Christi \\ Dr. Bounlieng Phommasouvanh \\ Minnesota Department of Education \\ Dr. Kalyani Rai \\ University of Wisconsin, Milwaukee \\ Dr. Nancy J. Smith-Hefner \\ Boston University \\ Dr. Myluong Tran \\ San Diego State University \\ Dr. Linda Trinh Vo \\ University of California, Irvine \\ Dr. Zha Blong Xiong \\ University of Minnesota
}

\author{
Dr. Stacey Lee \\ University of Wisconsin, Madison \\ Dr. Sue Needham \\ California State University, Dominguez Hills \\ Dr. Max Niedzwiecki \\ Daylight Consulting Group \\ Dr. Clara Park \\ California State University, Northridge \\ Dr. Loan T. Phan \\ University of New Hampshire \\ Dr. Karen Quintiliani \\ California State University, Long Beach \\ Dr. Fay Shin \\ California State University, Long Beach \\ Dr. Yer J. Thao \\ Portland State University \\ Dr. Khatharya Um \\ University of California, Berkeley \\ Dr. Zha Blong Xiong \\ University of Minnesota \\ Dr. Kou Yang \\ California State University, Stanislaus
}

\section{Doctoral Student Editorial Review Board}

\author{
Keo Chea-Young \\ University of Pennsylvania \\ Peter Tan Keo \\ Columbia University \\ Ravy Lao \\ University of California, Santa Barbara \\ Vanna Som \\ Harvard University \\ Layheng Ting \\ State University of New York, Albany \\ Tinou Tran \\ University of Houston, Texas
}

\author{
Annie BichLoan Duong \\ San Joaquin County Office of Education \\ Ha Lam \\ Arizona State University \\ Giang Pham \\ University of Minnesota
}

Rassamichanh Souryasack

University of California, Santa Barbara

Loan Tran

University of California, Santa Barbara

Phitsamay Sychitkokhong Uy

Harvard University

Yang Sao Xiong

University of California, Los Angeles 